\title{
Biomass as An Alternative Energy Source: Recent Progress and Development Based on Thermal Processes to Respond to the Future Energy Mix in Indonesia
}

\author{
J.P. Simanjuntak ${ }^{1}$, E. Daryanto ${ }^{2}$ and B.H. Tambunan ${ }^{3}$ \\ \{janterps@gmail.com ${ }^{1}$, ekadaryanto@unimed.ac.id ${ }^{2}$, bisrulhapis@gmail.com ${ }^{3}$ \} \\ Universitas Negeri Medan,Mechanical Engineering Department, Medan ${ }^{1,2,3}$
}

\begin{abstract}
The purpose of this article is to review and share the information as well as an achievement that has been obtained in the field of solid biomass waste into energy conversion in Indonesia especially on thermal processes. The future energy in Indonesia has been prepared since long time ago which can be known from the research activities and scientific articles that have been published in journals and also through local social media. Energy resilience in the future is prepared to respond to an increase in the human population, development in all fields that certainly requires quite a lot of energy. Biomass is one of the potential future energy sources which are considered as waste. In addition to its abundant, biomass is known to be environmentally friendly because it does not contribute to the air pollution, does not cause the greenhouse effect, and does not cause climate and weather changes. Several efforts to support Indonesia's energy mix in the future based on thermal processes were reported.
\end{abstract}

Keywords: Solid biomass, Combustion, Gasification

\section{Introduction}

Industrial Revolution 4.0 is a big challenge for Indonesia as a developing country with a large population. In developing country, Indonesia requires a lot of high technology equipment that can be used to support the development. Many things can be done using equipment so that the use of manpower is reduced. This is called the era of disruption which is characteristic of the 4.0 Industrial Revolution. To overcome these problems, the government must encourage the development of several crucial sectors. However, the main problem arises is energy that need to drive all developing sectors. The fact that Indonesia's main source of energy still dominated by fossil fuels. The negative effect of fossil utilization is human civilization damage since the past. As an addition, the most issue is about harmful climate change. Therefore, the most appropriate solution is to replace the fossil fuel into renewable carbon neutral energy sources.

Transportation sector, especially personal vehicles will become the most electric users in year 2050 due to the President Regulation No. 55/2019 issue concerning the Acceleration of the Battery-Based Electric Motor Vehicle Program for transportation and also the Government Regulation No. 73/2019 which sets the amount of exhaust emissions and also the fuel consumption of vehicle. Both regulations encourage the use of electrical energy as the driving 
force and of course will require the electric charger infrastructure. The two regulations also intended to reduce the fossil fuel utilization to mitigate the impact on climate change.

Until now climate change has become the center of global attention because it causes a huge negative impact. There is no other choice except to encourage the utilization of green energy sources, such as biomass that is classified as a renewable energy source. However, several problems in developing biomass include investment and operational costs are still high, short live time of equipment, air pollution, and light particles problem that are released free into the air, biomass collection, transportation, and processing. Indonesia has committed to reduce the use of fossil fuels and utilize biomass energy to $17 \%$ of the total national energy mix due to Indonesia's support for the Paris agreement. However, the government hopes that the implementation of biomass as an alternative energy does not conflict with food supply and environmental conservation in order to reduce the impact on climate change.

The depletion of the main energy production especially oil and gas, has encouraged the government to make renewable energy to a top priority for maintaining national energy security and independence. To safeguard the future energy sector's readiness, the use of renewable energy has already begun. But, Indonesia faced with three serious problems in developing biomass as energy sources, namely the regulation, the environmental aspect, and infrastructure problems. This has a negative impact on the development and growth of energy which determines the readiness of the energy mix in the future. Until year 2018, the portion of electric supply is still dominated by the state electricity company or Perusahaan Listrik Negara (PLN) with coal as the fuel as shown in Fig 1 below.

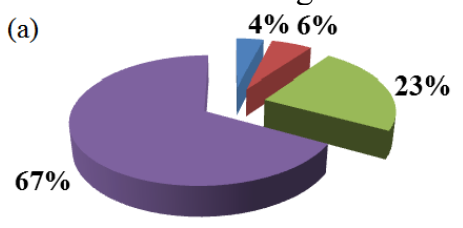

- PPU $\backsim$ NON FOSIL $⿴$ IPP $\approx$ PLN

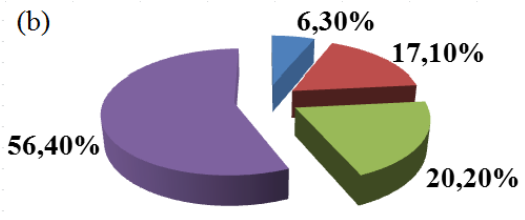

Fuel Oil $\because$ Renewable $\square$ Gas $n$ Coal

Fig 1. State electric capacity in year 2018 (a) based on supplier, (b) based on fuel (Direktorat Jenderal Ketenagalistrikan, 2018)

Biomass potential in Indonesia is very large and can be utilized as a national energy supply in the future. However, biomass energy is currently not fully utilized. Based on Presidential Regulation No. 22/2017 concerning the National Energy General Plan, it is stated that $23 \%$ of the national energy mix in 2025 is expected to be supplied from renewable energy as shown in Fig 2 . This target is equal to $45 \mathrm{GW}$ of generating capacity. At present the installed renewable energy generating capacity is still $9 \mathrm{GW}$. It means that an additional $36 \mathrm{GW}$ is needed until 2025. The achievement during year 2015-2018 periods reached only 5\% while to pursue the target by 2025 required up to $10 \%$ achievement each year. Seeing this reality, the government is pessimistic that the $23 \%$ in year 2025 will be achieved.

According to the national statistical data center or Badan Pusat Statistik (BPS) review year 2019, Indonesia should be more massive in developing renewable energy-based power plants. However, the energy mix used to generate electric from year 1998 to 2018 is still dominated by the coal whilst electric generation from renewable energy still retarded even though these energy sources are very abundant. BPS review 2019 also pointed out that the contribution of renewable energy is only $5.5 \%$ of the total electric generation in 2018 . This slight increase compared to year 2017 by $5.3 \%$. There is also a target to new and renewable energy mix (EBT) in 2020 by 
$17 \%$, while in 2025 is expected to reach $23 \%$, and in 2050 the contribution is expected to have reached $31 \%$ as shown in Fig 2 below.

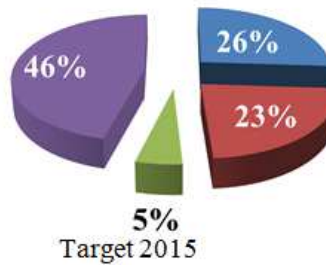

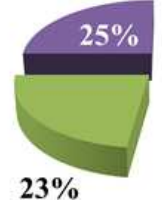

$23 \%$

Target 202

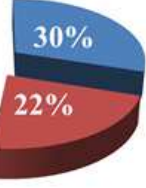

25

$\begin{array}{lll}\text { - Renewable energy } & \text { O Oil } \\ \text { - Natural Gas } & \bullet \text { Coal }\end{array}$

$\begin{array}{lll}\text { - Renewable energy } & \text { O Oil } \\ \text { - Natural Gas } & \text { - Coal }\end{array}$

Fig 2. Indonesia energy mix target by 2015 (RUEN)

The current energy mix to support Indonesia's development comes from coal, crude oil, natural gas, hydropower, and renewable energy. Specifically for renewable energy, to date, as a wholly renewable energy still accounts for 3\% [1]. This situation is relatively low considering the abundant potential of renewable energy. At present, the government's attention begun to look at this new energy source, but the management is not yet perfect. The government target that the installed electric capacity energy from biomass in 2050 about $4 \%$ as shown in Fig 3 .

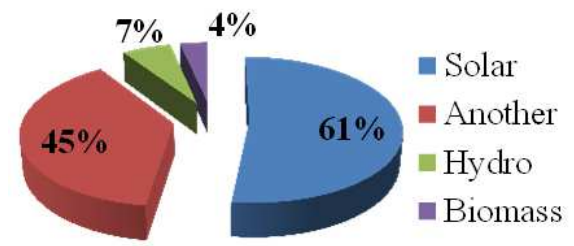

Fig 3. The installed capacity of electrical energy from EBT in 2050 (RK) [2]

\section{Recent activity on university laboratory-based}

The motivation for developing biomass as a renewable energy source is referred to the Minister of Energy and Mineral Resources Regulation No. 12/2019 which mentions and regulates the generation of electricity from biomass for one's community by obtaining an operating permit. To get energy from biomass, a conversion process is carried out, most of which use high-temperature called thermochemical processes that requires a suitable reactor. Indonesia so far has been made efforts to increase the economic value of biomass by using thermal process technology which until now continued to improve its performance [3-9] . Several studies have been conducted in Indonesia related to the use of biomass as an energy source. The following figures are the research progress and development of biomass into energy conversion, especially electrical energy that can be used in the district yet connected to the national electricity grid. 


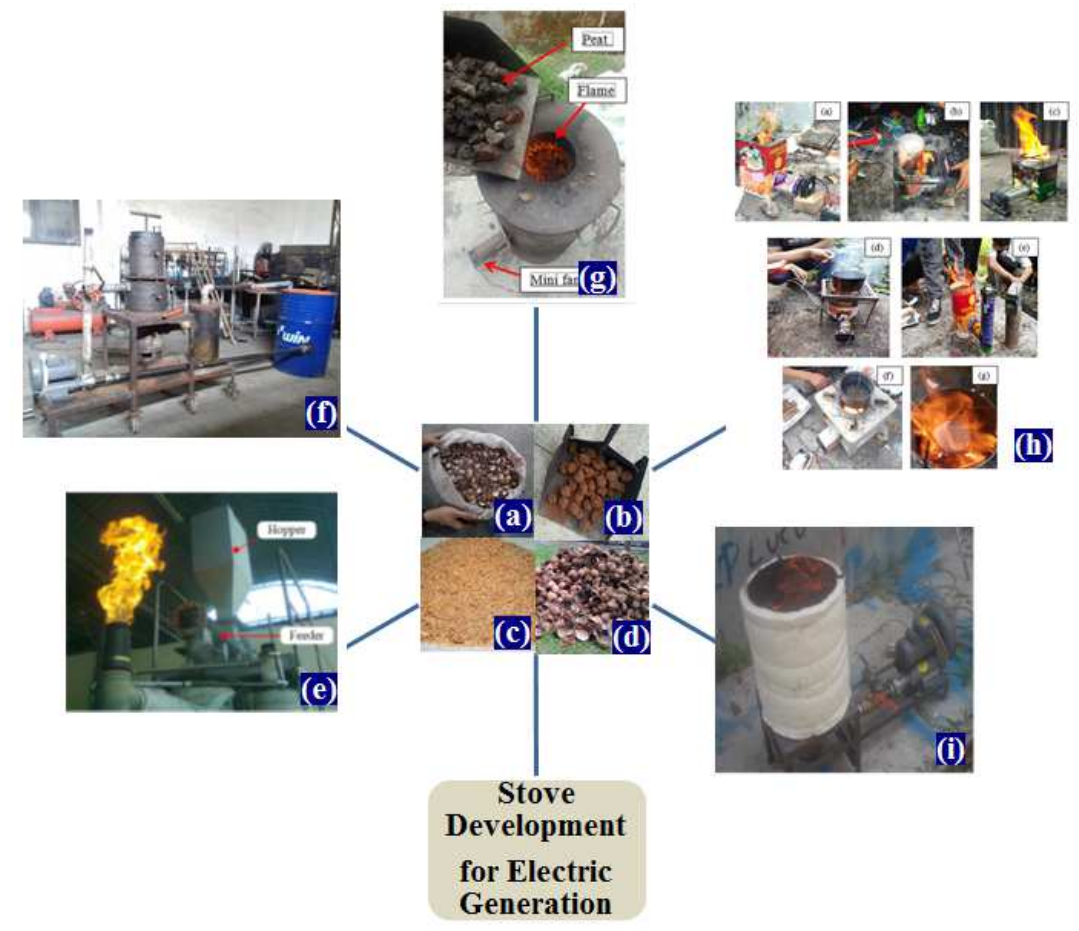

Fig 4. Biomass to energy project laboratory-based

Some agricultural residues as shown in Fig 4 such as (a) Candlenut shells, (b) Coconut shells, (c) Sawdust, and (d) Peat soils are tested by using the gasifiers and stoves. Fig. 4e showed the gasification with sawdust as feedstock. With the new design reactor used, an internally circulating fluidized bed is an attractive to produce flammable gas contain heating values close to $7 \mathrm{MJ} / \mathrm{m}^{3}$ [5]. Based on local biomass, the reactor must be adjusted; the fixed-bed gasifier model may be used as shown in Fig. 4f. By using a downdraft gasifier type, the candlenut shell and coconut shell can be used to produce flammable gas [10]. Gasification and combustionbased furnaces are also developed referring to the implementation of biomass technology that suitable for use in areas where biomass is found. Biomass in Fig. 4a to $4 \mathrm{c}$ also produce potential thermal energy with the gasification process as shown in Fig. $4 \mathrm{~g}$, this is known from the temperature of the fire generated [11]. Fig. 4 is the development of a biomass burning furnace. Some conventional stoves were modified and tested using coconut shells. Through modification, it is obtained that the furnace with an external combustion air supply has the best performance shown by fire temperature [12].

Energy from biomass is also another option to drive the engines in the future. But until now the fuel for transportation is still dominated by liquid fuels and natural gas according to President Regulation No. 64/2012 [13, 14]. However, along with technology developments, the use of gas for engine has also begun to be developed to replace liquid fuels. In Indonesia, the use of gas for engines has a promising future in transportation sector. They concluded that the fuel gas from biomass with a minimum heating value $\left(3 \mathrm{MJ} / \mathrm{m}^{3}\right)$ can be used to drive the engine. 


\section{Power plant development biomass-based in Indonesia}

Until now, government policies in the energy law have yet to be realized concerning the matters previously explained, especially the utilization of biomass into electrical energy by utilizing power plants. The following is the information on biomass-based power plan in Indonesia collected from the internet.

Table 1. Recent power plan based biomass in Indonesia

\begin{tabular}{|c|c|c|c|c|c|}
\hline No & Location & Capacity & Biomass & Technology & COD \\
\hline 1 & Kalimantan Barat & $15 \mathrm{MW}$ & Palm shell & Gasification & 2018 \\
\hline \multirow[t]{3}{*}{2} & Kalimantan Tengah & $10 \mathrm{MW}$ & Palm shell & Combustion & N.D \\
\hline & & $10 \mathrm{MW}$ & Palm shell & Combustion & N.D \\
\hline & & $10 \mathrm{MW}$ & Palm shell & Combustion & N.D \\
\hline \multirow[t]{5}{*}{3} & Kalimantan Barat & $10 \mathrm{MW}$ & Palm shell & Combustion & N.D \\
\hline & & $15 \mathrm{MW}$ & $\begin{array}{l}\text { Palm shell, Rice } \\
\text { husk, Corncob, } \\
\text { Sugarcane Bagasse }\end{array}$ & Combustion & 2018 \\
\hline & & $10 \mathrm{MW}$ & Palm shell & Combustion & N.D \\
\hline & & $4 \mathrm{MW}$ & Palm shell & Combustion & N.D \\
\hline & & $1 \times 15 \mathrm{MW}$ & Palm shell & Combustion & N.D \\
\hline \multirow[t]{2}{*}{4} & Mentawai, Sumatera & $300 \mathrm{~kW}$ & Bamboo & Combustion & 2018 \\
\hline & Barat & $150 \mathrm{~kW}$ & Bamboo & Combustion & N.D \\
\hline \multirow[t]{3}{*}{5} & Sumatera Utara & $2 \times 15 \mathrm{MW}$ & $\begin{array}{l}\text { Palm shell, } \\
\text { Corncob, Sawdust, } \\
\text { Rice husk }\end{array}$ & Combustion & 2012 \\
\hline & & $1 \times 9,9 \mathrm{MW}$ & Rubber wood & Combustion & 2020 \\
\hline & & $1 \times 15 \mathrm{MW}$ & Rubber wood & Combustion & N.D \\
\hline 6 & Jambi & $10 \mathrm{MW}$ & Palm shell & Combustion & N.D \\
\hline 7 & Cilegon & $1 \times 15 \mathrm{MW}$ & Palm shell & Combustion & N.D \\
\hline 8 & Nias, Sumatera Utara & $18 \mathrm{MW}$ & Bamboo & Combustion & N.D \\
\hline 10 & Sumba & $1 \mathrm{MW}$ & $\begin{array}{l}\text { Bamboo, Wood } \\
\text { chips }\end{array}$ & Combustion & N.D \\
\hline 11 & Bali & $150 \mathrm{~kW}$ & Wood pellet & Combustion & N.D \\
\hline 12 & Sulawesi Tengah & & Corncob & Combustion & N.D \\
\hline 13 & Sumatera Selatan & $3 \mathrm{MW}$ & Rice husk & Combustion & N.D \\
\hline
\end{tabular}

COD: commercial operating date

N.D : not detected

\section{Closing remarks and future works}

Progress and achievements towards the biomass to energy conversion in Indonesia has been presented. Until now, the development and improvement of the reactor performance are very rapid. Specifically for gas fuel (syngas) from biomass, it is strongly recommended by the writer's and team to develop this technology until syngas is obtained properly which can be applied to engines. 


\section{Acknowledgements}

The authors would like to acknowledge the Universitas Negeri Medan for financial support through DIPA with Contract Number 292D/UN33.8/PL/2019. The authors highly acknowledge support from mechanical engineering workshop members, and also two final project students for their participation and contribution to this project.

\section{References}

[1] Hasan, M.H., T.M.I. Mahlia, and H. Nur, A review on energy scenario and sustainable energy in Indonesia. Renewable and Sustainable Energy Reviews, 2012. 16(4): p. 2316-2328.

[2] Nasional, D.E., Indonesia Energy Outlokk 2019 (2019)..

[3] Indonesia, P.R., Peraturan Pemerintah Republik Indonesia Nomor 79 Tahun 2014 Tentang Kebijakan Energi Nasional. Jakarta (2014).

[4] Simanjuntak, J.P., Experimental and Simulation Study of an Internally Circulating Aerated Fluidized Bed Gasifier with Concentric Cylinders. Universiti Sains Malaysia (2014).

[5] Simanjuntak, J.P. and Z.A. Zainal, Experimental study and characterization of a two-compartment cylindrical internally circulating fluidized bed gasifier. Biomass and Bioenergy, 77: p. 147-154 (2015.

[6] Simanjuntak, J.P., A.A. Khaled, and Z.A. Zainal, Hydrodynamic flow characteristics in an internally circulating bubbling fluidized bed gasifier. Journal of Energy Resources Technology, 2018.

[7] Simanjuntak, J.P., et al., Producer gas production of Indonesian biomass in fixed-bed downdraft gasifier as an alternative fuels for internal combustion engines. Journal of Physics: Conference Series, 970(1): p. 012019 (2018).

[8] Daniyanto, et al., Torrefaction of Indonesian Sugar-cane Bagasse to Improve Bio-syngas Quality for Gasification Process. Energy Procedia, 68: p. 157-166 (2015).

[9] R. Alamsyah, E.H.L., E. Susanto, Eko, and L.J. Susanto, N.C. Siregar, An Experimental Study on Synthetic Gas (Syngas) Production through Gasification of Indonesian Biomass Pellet. Energy Procedia, 65: p. 292-299 (2015).

[10] Simanjuntak, J.P., B.H. Tambunan, and E. Daryanto, Karakterisasi Biomassa Lokal Sebagai Bahan Bakar Alternatif Menggunakan Reaktor Penggas Tipe Downdraft (2016)..

[11] J. P. Simanjuntak, B.H.T., H. Efendi, R. Silaban, S. Riadi, D. Pasaribu, A Preliminary Study of Peat Gasification Characteristics in an Improved Biomass Stove. Proceedings of the 2nd Annual Conference of Engineering and Implementation on Vocational Education (ACEIVE 2018), 3rd November 2018, North Sumatra, Indonesia.

[12] J.P. Simanjuntak, E.D., B.H. Tambunan, Experimental and Performance Assessment of Indonesian Biomass-Fired Based Stove with Internal Air Box using Coconut Shell. Proceedings of The 5th Annual International Seminar on Trends in Science and Science Education, AISTSSE 2018, 18-19 October 2018, Medan, Indonesia, (2019).

[13] Nomor, P.P., Tahun 2012 tentang Penyediaan. Pendistribusian, dan Penetapan Harga Bahan Bakar Gas untuk Transportasi Jalan.

[14] Shahbaz, M., et al., Optimization of hydrogen and syngas production from PKS gasification by using coal bottom ash. Bioresource Technology, 241: p. 284-295, (2014). 